\title{
EFFECT OF GIVING SCAPULAR PATTERN EXERCISE FOR INCREASION RANGE OF MOTION IN FROZEN SHOULDER
}

\author{
Aulia Muthia Muthmainnah, Afif Ghufroni, M.Mudatsir Syatibi
}

School of Health Polytechnics, Surakarta

\begin{abstract}
Background: Frozen shoulder is a shoulder joint disorder that occurs in 2-5\% of the world's total population and causes pain, causing shoulder joint motion to be limited. Limited range of shoulder joint motion in frozen shoulder causing diminished functional activity ability. This research aims to determine the effect of giving training on scapula patterns to increase the range of shoulder movement in frozen shoulder case.

Subjects and Method: This was an experimental study with one groups pre and posttest design. This study was conducted for 4 weeks with 8 times treatment at RSAL Dr. Ramelan Surabaya. The subjects selected in this study were six persons based on criteria for inclusion and exclusion. The dependent variable was shoulder range of motion. The independent variable was scapular pattern exercise. The data were collected by goniometer instrument and analyzed by paired T test.

Results: Paired T test showed that shoulder range of motion exorotation $(\mathrm{p}=0.001 ; 95 \% \mathrm{CI}=-$ 15.95 to -7.38$)(\mathrm{Mean}=11.67 ; \mathrm{SD}=4.08)$, shoulder range of motion abduction $(\mathrm{p}<0.001 ; 95 \%$ $\mathrm{CI}=-50.75$ to -39.25$)(\mathrm{Mean}=45.00 ; \mathrm{SD}=5.48)$, shoulder range of motion endorotation $(\mathrm{p}<$ $0.001,95 \% \mathrm{CI}=-29.73$ to -15.27$)(\mathrm{Mean}=22.50 ; \mathrm{SD}=6.89)$.

Conclusion: Scapular pattern exercise can be recommended as a therapy to increase the range of motion of the shoulder joint in cases of frozen shoulder.
\end{abstract}

Keywords: frozen shoulder, shoulder range of motion, scapular pattern exercise, goniometer.

\section{Correspondence:}

Aulia Muthia Muthmainnah. School of Health Polytechnics, Surakarta. Jl.Adi Sumarmo, Tohudan, Karanganyar. Email: aulmuthia.physio@gmail.com. Mobile: 082320934461

The $7^{\text {th }}$ International Conference on Public Health Solo, Indonesia, November 18-19, 2020 379 https://doi.org/10.26911/the7thicph.05.11 